\title{
Transformasi Ruang 2D Ke 3D Pada Animasi Wajah Berbasis Data Marker Menggunakan Radial Basis Function
}

\author{
Troy $^{1)}$, Pranowo ${ }^{2)}$ \\ Magister Teknik Informatika \\ Fakultas Teknik, Universitas Atma Jaya Yogyakarta \\ e-mail:155302474@students.uajy.ac.id ${ }^{1)}$,pran@mail.uajy.ac.id ${ }^{2)}$
}

\begin{abstract}
Abstrak
Teknik komputasi yang dikembangkan pada animasi wajah bertujuan untuk menciptakan ekspresi pada wajah karakter animasi senatural mungkin seperti layaknya ekspresi pada wajah manusia. Menggunakan data marker pada citra 2D wajah manusia, komputer menangkap pergerakan marker tersebut kemudian menetukan lokasi titik fitur yang pada wajah model 3D (karakter animasi).

Untuk mengatasi perbedaan morfologi pada wajah manusia yang menjadi sumber acuan ekspresi dengan wajah model 3D yang menjadi target animasi, maka diterapkan transformasi ruang Radial Basis Function (RBF). RBF digunakan untuk menentukan posisi titik fitur pada wajah model 3D berdasarkan posisi titik marker pada citra 2D wajah manusia.

Transformasi ruang RBF memiliki kemampuan yang baik dalam pemetaan ulang titik marker dari wajah manusia ke titik fitur pada wajah karakter animasi. Pergerakan yang terjadi pada wajah model 3D berdasar pada skala relatif antara titik marker pada citra 2D wajah manusia dengan titik fitur pada wajah model 3D.
\end{abstract}

Kata kunci: animasi wajah, radial basis function, data marker.

\section{Abstrak}

Computer facial animation aims to create an animated character expression as natural as possible as well as human facial expressions. Using the data marker catches facial motion capture, will be determined the location of the feature points of $3 D$ face models to follow the motion of the marker points of human faces.

To overcome the morphological differences between the face of the source with the character's face, then applied with radial basis retargeting process mapping so that the character's face can still display the natural expression. Using the data marker 2D, Radial Basis Function (RBF) space transformation was applied to determine the position of the feature points on the $3 D$ face models.

$\mathrm{RBF}$ space transformation has good ability in determining the appropriate facial motion marker points on a human face to the character's face. Motion that occurs in $3 D$ face models is scaled according to the relative scale between the source and the target.

Keywords: facial animation, radial basis function, marker data. 